高く，前者は，呼気流速の增大が著しいのK反し，後者 は，流凁の增加をみなかった。

声門下压と声門抵抗之の関係流，会話音域では，声門 下王の増加につれ声閒抵抗は，直線的に增大する事加知 られた，しかしこの関係法，喉頭疾患にも同様な傾向を 示すも，正常に比し限られた箚明に限定された。

正常では，弱い声加ら大きい声までの声門抵抗は11.8 $\sim 67 \mathrm{cmH}_{2} \mathrm{O} / \mathrm{L} / \mathrm{sec}$ を示したが，反回神経麻燂群では， 53.3 140 $\mathrm{cmH}_{2} \mathrm{O} / \mathrm{L} / \mathrm{sec}$ となり, 喉頭癌では症例处 り区々であった。

発声時の哄頭効萃は, 最終的儿は発声のためのエネル ギ一が，音声エネルギーに变换される率を求めることに あると考える。

すなわち

$$
\text { Glottal Efficiency }=\frac{\text { Acoustic Power }}{\text { Glottal Resistance }}
$$

イて表わされる值で評何されるが，今回数程疾患に打 け名 glottal resistance を求め大. しかし, 成綪仁み るごとく，発声時音声の大きさにより，声师下王，流速 共飞変動がみられる。このこしは，発声時の軟起声， 硬起声の状態により，声門下王は著しく異なったり，ま た文章会話に执いても，同一人でも持繹時間の長短に上

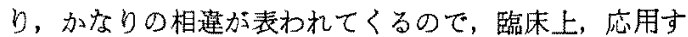
る場合に，発声条件の規定之，発声時のどの部位を測定 点とするかの選定等, 今後残された重要な問题となると 考えられた。

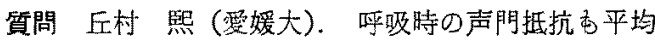
声門下王と平均呼気流加吕計算したか。分答 岩田 重信 声阴抵抗は，声帯振動 cycle 等でなく，平均的值 Кついての洞定である。

(B 82-1052-60522)

\title{
88. 音声の強さに関する検討
}

\author{
○卵内 就 (边川日赤) - 富山知隆・坂本伸雄（旭川医大）－小宮山荘太郎（九大）
}

音声障害の検㚗法は古来より生理学的あるい病理学 的見地より種々の方法が提唱された．近年音声障害を多 次元的に提え，分析しようとする試みがなされている. しかし强さの检查法汇関してはまだ確立されたすのはな いようである.小宮山は音声の 3 要素（高さ・強さ・音 色）の弓高さと强さを2次元的炕表示する方法を報告 し1，また，これを自動的に X-Yオシロスコープに表示 出来る phonometer 渚作発表している ${ }^{2}$ 。昨年われわ れはこの phonometer 忞用いて小学生备学年男子10名 - 女子 10名 合計 120 名の声の発達に䗡して検討老行い 報告した．今回昨年に引き続き同様の方法で中学生・高 校生各学年男子 10 名, 女子10名合計120名について貔討 を行ったので報告した。

\section{置およで検查方法}

Sound level meter (リオン社・ $\mathrm{Na}-09)$ ，デープレコ ーダー (AKAI・X-150D) むよび phonometer ${ }^{22}$ を用 いた，湘定方法は，被験者にでき得る限り口を大きく開 けさせ $/ \mathrm{a} /$ 発声で, $\mathrm{p}$ ・ml・f の強さの発声をさせた. 音声の高さは話声位とした。これをマイクロ唇間距雄を $20 \mathrm{~cm} と し$, sound level meter を通して phonometer 几描画させた.この検查を of lineで行う場台は，テ 一プレコーダーに録音し， phonometer K描画させる方 法をとった. phonometer の X-Yオシロコープは横軸

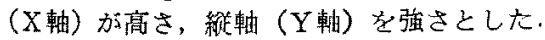

対象

12葴から17藏までの各年龄について男子10名・女子10 名 合計120名について検罚した。

啨果

1）年齢による音声の强さの発達について，

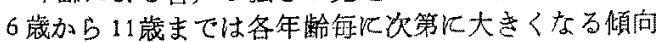
が認められたのに対し今回の調查籍囲の年得では大きく

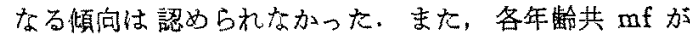
$\mathrm{p}$ と $\mathrm{f}$ 間伅バランスよく配置されていることが認めら れ，これは話声位が $\mathrm{p}$ と $\mathrm{f}$ 発声の中間に位置している こと起示唆している。

2) 男子と女子の声の強さの比較

男子と女子の声の強さについて年龆每に比较険行を行 った. その結果明らかに $\mathrm{p} \cdot \mathrm{mf} \cdot \mathrm{f}$ 発声とも男子の方が 女子より强い傾向を示した。

3)强さの苳動度

持続発声に括け尚 $\mathrm{p} \cdot \mathrm{mf} \cdot \mathrm{f}$ 発声の强さの变動度を比 較検討した、それそれの間の著明な差は認められなかっ たが $\mathrm{f}$ 発声が一番 変動度が小さくなる傾向が認められ た.

4) 強さと高さとの閣係

$\mathrm{p} \cdot \mathrm{mf} \cdot \mathrm{f}$ 発声の声の強さと高さの関係を調べた， $\mathrm{p} ・$ $\mathrm{mf} \cdot \mathrm{f}$ と声の强さが增すにつれて高さも增加することが 認められた。 ま12歳より男子と女子の声の高さの造い が認められた。

\section{考察}

ラリンゴマイクロサージャリーなど音声外科の発達に 伴い術前・術後の音声の状態を正確に把握することが必 要になってきたことは勿墖のこと, 日常臨床において “高い声加出ない。“大きい声が出ない”等のように声

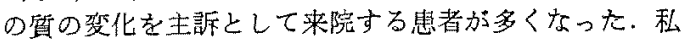
共が用いている phonometer は声の高さをX軸, 强さを

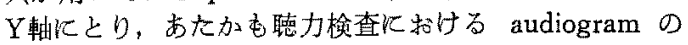
ような性格をもって抲り音声を多元的にみつめる検査法 のひとつですると考克る。われわれは䝫年の小学生に引 き続き中学生・高校生について調查し“音声の強さ”の

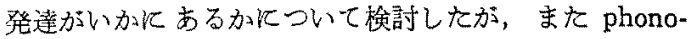

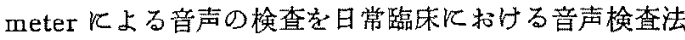


として確立することむ目的とした，小学生では学齡が增 すにつれて强さの愊が增加する傾向が証められたが中学

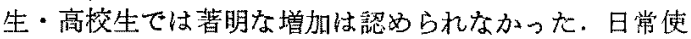
用される声の強さの䈌用が一定に達したと思われた。こ

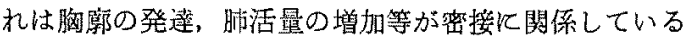
と思われた，恎声の强さの变動度が $\mathrm{f}$ 発声で一番小さい ことは小学生の場合と同様であった．このことは渡辺等 の報告と香一致しており，今後この点を詳しく調榃する ことが必要と思われた. 男子の声と女子の声では男子の 方が強い発声であり。このことは小学生でも同様で年秢 几関係なく男子の方が女子より強い発声であると思われ た，音声の强さと高さの関係では強さが增すにつれて高 さあ增加することが認められた。

まとめ

1) 中学生・高校生の音声の発達, 特化音声
発達がいかにあるが phonometer を用いて調查した。

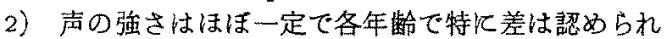
なかった。また男子が好よりも強い発声であった。

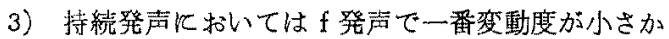
っ

4) 声の強さが增すにつれ高さむ增加した。また男子 の声と女子ので声心明らかな高さの量いが認められた。

文献

1) 小宮山荘太郎：音声の新しい評価法耳學，18: 428, 1972.

2）小宮山荘太郎：phonometer の試作 耳奥，23:105, 1977 .

3）渡辺 宏: 音声の強さに関する検查法 耳舅，23： 33,1977

(B 82-1053-60082)

\section{9. 音響的手法による知頭機能の評価}

\section{今泉 敏・太田文彦・小池站夫・文珠敏郎・米川絃子・阿部博香（近畿大）}

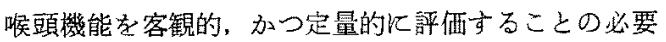

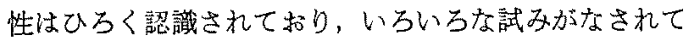
いるが精度が高く，臨床的応用が可能であるような，渵 足すべき方法はまだ確立されていない。

われわれは，喉䫄機能の障害に伴う病的文声の評価を 手珈りとして，喉頭機能を把握し，表示する試みを続 けてきた。

今回㤬，臨床の場で使用し得ることを目標として設計 した音篦分析法と，合成音声を基準音として利用する聴

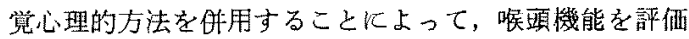
するため有用な知見を得たので報告する。

病的音声り音筴的性翼の記载のためには，ディシタル 信号処理技術を利用して，音響分析を行ない，その結果 を数㑑的化記載するのが，最も高精度である上考えられ る.病的音声の音響分析をミーコンピュータで行なう方 法としては，声道の伝達特性を音声波形加らとりさるこ

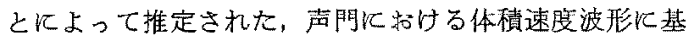
ずくものと，線型予测法に拈ける残差波形飞基ずく方法

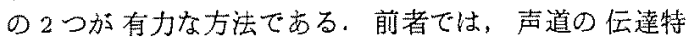
性を推定するために，何らかの方法で，ホルマント周波 数とそのバンド幅を推定する必要がある，そのために， 分析者加ある程度，処理過程に介入する必要加あり，自 動処理加むずかしいこと，推定誤差が分析結果に影響す ることなどの難点があるが，分析結果は生理的な解哌が しやすいという利点老むつ，一方，後者は，自動処理が 可能であることから，臨床的応用には適している，しか し，残差波形は，声門反招ける体積速度波形のるつ情報 をすべて含んでいるとはいいがたいことから，生理的解 釈は必ずしも明磼でない。

そこてわれわれは，臨床的応用の可能性の最京い方 向として，線型子測法を応用することによって自動的に 声阴に扮ける体積速度波形の近似波形を抽出し，それに
基ずいて，喉頭機能を評佂する方法と考光，抽出方法儿 ついてさらに検討を加亲ている。

このような音整分析の結果得られる音留的パラメータ は，声門江括りる体精速度波形の高調波成分の多少，雑 音成分の多少とそれが存在する周波数带域，基本周波数 と振輻の立上り，立下り時間および定常部でのゆらぎ幅 とその速さなどである。これらの音響的パラタータが， 病的音声の音響的性質を特徽ずけるということは，䟽計 的に確かめられている。しかし，これらの音輩的パラメ

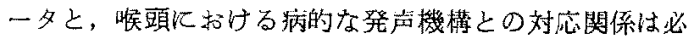
ずしも明確でない，そこですれわれは，㘈ストロボス コープや高速度陕画などによる声带振動の観測や，声門 下圧の测定などの手段を用いて，静的並に動的観察， 記録を行ない，得ら机た生理的情報を音蝆的パラォータ と比較し，检討している。例えば，日常的な臨床の場て は，喉頭ストロボスコープを用いて，声带振動の振幅， 粘膜波動の大き车右の声带の振動の位相差について の所見を記録し，音響分析の結果の臨床的な応用価值を 確加るための基準としている。

以上のような分析的手法によって，喉䫒機能を評価す る方法に較べて，より簡単な方法として，病的音声の聴 筧心理的評洒を通して，喉謴機能を評価する方法があ 万.

この方法を用いる場合，目的に合万評価尺度の選定が 因櫵であることに加えて，判定者の主観的要因によって 評俩で変動するという難点がある。われれれは，これら の閔題を解决するために，音響的パラメータを種々の值 に指定して作成した合成音を用いて，種々の聴取実駼を 行なった。

その絬果，合成音声を基渒音として，息者音声と一対 比較を行なら方が基準音なしに語洒をつけるよりも，判 定者の違いによる評価の变動方小さく，䧟切な評価尺度 